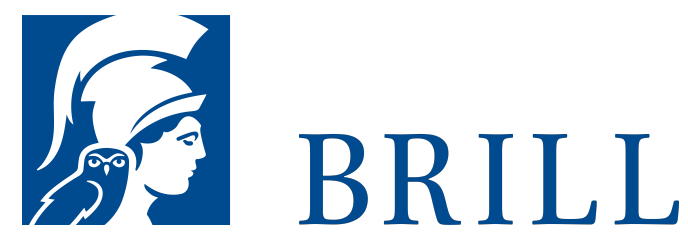

\title{
The Textual Tradition of the Gospels
}

\author{
Family 1 in Matthew
}

Author: Amy S. Anderson

This investigation of the 1oth century minuscule Codex 1582 in the Gospel of Matthew includes a description of the physical document and an extensive evaluation of the text it contains. The manuscript was copied by the monk Ephraim, who is known to scholars in various fields. The high quality of his work and of the documents which were available to him demonstrate that he carefully reproduced an exemplar which witnessed to an ancient and valuable text. The text and marginal variants of Codex 1582 are shown to be related, though not identical, to the text of Matthew used by Origen, raising the possibility of a Caesarean archetype. A full collation of Codex 1582 to Codex 1 demonstrates that $15^{82}$ should be the leading member, as well as the basis for the age and readings of Family 1 in Matthew. Test collations of twelve other supposed family members lead to a re-evaluation of the interrelationships of the documents and an expanded stemma of the family.

\section{Readership}

New Testament textual critics, palaeographers, exegetes, academic libraries, specialists in Greek, specialists in the textual traditions of Polybius, Aristotle, and Plato, as well as those interested in 1oth century scriptoria and book collections.

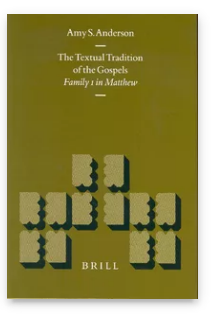

Pages: $\mathrm{x}, 222 \mathrm{pp}$, 32 illus.

\section{Language: \\ English}

Subjects: New

Testament \&

Early Christian

Writings,

Biblical Studies

Publisher: Brill

Series:

New Testament

Tools, Studies

and Documents,

Volume: 32

E-Book (PDF)

Released online:

26 Nov 2019

ISBN: $978-90-$

04-380oo-4

List price

USD $\$ 182.00$

\section{Hardback}

Publication date:

19 Dec 2003

ISBN: $978-90-$

04-13592-5 
Amy S. Anderson, Ph.D. (1999) in Theology, University of Birmingham, England, is Associate Professor of Greek and New Testament at North Central University in Minneapolis, Minnesota.

For more information see brill.com

$$
\begin{aligned}
& \text { Order information: Order online at brill.com } \\
& +4433 \circ 333 \text { o049 | customerservices@brill.com } \\
& \text { Submission information: brill.com/authors }
\end{aligned}
$$

Titles published by Brill | Fink, Brill | mentis or Brill| Schöningh: +49(o)71 5413279216 | brill@brocom.de 